\title{
STRATEGI KOPING ADAPTIF DALAM MEREDUKSI STRES CAREGIVER LANSIA
}

\author{
Bambang Setiawan \\ Fakultas Ushuluddin Adab dan Dakwah, IAIN Syekh Nurjati Cirebon \\ Email: setiawan89.bambang@ gmail.com
}

\begin{abstract}
Naturally, the emergence of stress is an individual's reaction to adjust to the stressor or source of stress individual faces. Coping strategies are needed by caregivers, especially dealing with stressors from waiting jobs. This study aims to determine the stress experienced by the elderly caregiver and the coping strategies used by the elderly caregiver at a nursing home in the city of Cirebon. The approach used in this research is qualitative method, which views social reality as something holistic, complex, dynamic and full of meaning, and focuses on the overall social situation under study covering aspects of places, actors and activities that interact synergistically. The sample technique used in this research is purposive sampling, the researcher deliberately selects individuals as participants and the location to be studied and the main phenomenon of research. Results Based on this study, it was found that the three caregivers in one of the nursing homes in Cirebon City experienced different stress categories. Inf. 1 experienced moderate stress category, while Inf. 2 and Inf. 3 experienced mild stress category. The coping strategies used by caregivers include: a) problem-focused coping; and b) emotion focused coping, which is carried out adaptively according to the stressor received by the caregivers.
\end{abstract}

Keywords : Adaptive Coping Strategy, Caregiver, Elderly People

\begin{abstract}
Secara alamiah, munculnya stres merupakan reaksi individu untuk menyesuaikan diri terhadap stressor atau sumber stres yang dihadapinya. Strategi koping sangat dibutuhkan oleh para caregiver, khususnya sangat menghadapi stressor dari tuntutan pekerjaan yang dilakukannya. Penelitian ini bertujuan untuk mengetahui stres yang dialami caregiver lansia dan strategi koping yang digunakan oleh caregiver lansia di salah satu Panti Wreda yang berada di Kota Cirebon. Pendekatan penelitian yang digunakan adalah pendekatan kualitatif, yang memandang realitas sosial sebagai sesuatu yang holistik, kompleks, dinamis dan penuh makna, serta memfokuskan pada keseluruhan situasi sosial yang diteliti meliputi aspek tempat, pelaku dan aktivitas yang berinteraksi secara sinergis. Adapun teknik sampel yang digunakan dalam penelitian ini adalah purposive sampling, peneliti dengan sengaja memilih individu sebagai partisipan dan lokasi penelitian yang akan diteliti dan dipahami fenomena utamanya. Berdasarkan hasil penelitian ini, diperoleh hasil bahwa ketiga caregiver di salah satu panti wreda yang berada di Kota Cirebon mengalami kategori stres yang berbeda. Inf. 1 mengalami stres kategori sedang, sementara Inf. 2 dan Inf. 3 mengalami stres kategori ringan. Adapun
\end{abstract}


strategi koping yang digunakan oleh para caregiver meliputi: a) koping berfokus pada masalah (problem focused coping); dan b) koping berfokus pada emosi (emotion focused coping), yang dilakukan secara adaptif menyesuaikan dengan sumber stres (stressor) yang diterima oleh para caregiver).

Kata Kunci : Strategi Koping Adaptif, Caregiver, Lansia

\section{PENDAHULUAN}

Seiring dengan bertambahnya usia individu, maka akan semakin besar kemungkinan seorang individu mengalami permasalahan fisik, psikologis, ekonomi dan sosial. Perubahan lainnya yaitu terjadi dalam hal perubahan fungsi emosi, kognitif dan spiritual. Dalam tahapan ini, lansia merupakan subjek yang akan mengalami kecenderungan dalam perubahan-perubahan tersebut. Hal ini disebabkan oleh menurunnya kondisi fisik, psikis maupun sosial, sehingga penurunan yang dialami lansia akan memperlambat proses interaksi dengan lingkungannya, (Triwanti, Ishartono, \& Gutama, 2015).

Pada dasarnya lansia sangat membutuhkan perhatian dan dukungan dari orang-orang terdekatnya, khususnya adalah anak ataupun cucu-cucunya. Akan tetapi, banyak ditemukan lansia yang tidak memiliki lagi keluarga, sehingga terpaksa hidup sendiri ataupun karena kesibukan anak dan cucunya menyebabkan lansia tersebut tidak terperhatikan. Fenomena yang terjadi pada lansia seperti ini, akhirnya beberapa lansia ditempatkan di Panti Wreda, baik yang dilakukan secara sukarela ataupun terpaksa oleh kondisi, (Cristanty \& Azeharie, 2016)

Panti wreda merupakan suatu instansi yang berupaya untuk menjaga dan meningkatkan kesejahteraan para lansia. Panti wreda memiliki peranan penting dalam meningkatkan kesejahteraan para lansia melalui layanan dan bantuan yang diberikan. Layanan dari panti wreda sendiri meliputi pemenuhan kebutuhan fisik, psikis, dan sosial untuk para lansia yang tidak terpenuhi ketika berada dalam lingkungan keluarganya.

Dalam menjalankan fungsi layanannya, terdapat para caregiver yang bertugas untuk merawat dan memberikan perhatian kepada para lansia penghuni panti wreda. Peran penting caregiver akan membantu para lansia untuk menyesuaikan diri dengan kondisi, lingkungan sosial baru dan menjaga agar para lansia tetap aktif dan sehat. Selain itu, caregiver juga bertugas) dalam menangani para lansia dengan perilaku, tingkat adaptasi dan permasalahan kesehatan yang berbeda-beda. Caregiver merupakan individu yang memberikan bantuan dan perawatan kepada para lansia, mulai dari membantu tugas sehari-hari seperti memandikan, memakaikan baju, memberi makan, memberikan obat, dan bahkan pula menjaga serta memberikan dukungan emosional kepada para lansia.

Dengan beragam watak dan kepribadian lansia menyebabkan bermacam perilaku yang ditampilkan oleh para lansia. Ada lansia yang mampu beradaptasi dengan baik, sehingga berperilaku normal. Tetapi ada pula lansia kurang mampu beradaptasi dengan baik, yang ditunjukkan dengan perilaku menyimpang seperti, tingkat emosional yang tinggi, munculnya gangguan psikoaktif yang ditandai dengan aktivitas 
tidak wajar misalnya berjalan tanpa henti sampai kakinya terluka, (Ariyani, 2013).

Selain itu, muncul perubahan perilaku lansia dimana berperilaku kekanak-kanakan. Hal ini seperti yang dijelaskan dalam Q. S. Yasin: 68 bahwa apabila manusia dipanjangkan umurnya dan telah memasuki usia lanjut, maka kemampuan didalam dirinya akan kembali sebagaimana manusia tersebut kembali ke awal penciptaanya (kanak-kanak). Selain dari perubahan perilaku lansia, rasio dalam memberikan layanan dari para caregiver juga sangat menentukan. Caregiver apabila melayani beberapa lansia sekaligus merupakan hal yang tidak mudah, dan akan menyebabkan kelelahan yang dialami oleh caregiver baik secara fisik maupun psikologis.

Kegiatan pelayanannya yang dilakukan secara terus-meneruh tersebut, akan besar kemungkinan dapat mempengaruhi terhadap berkurangnya waktu dari para caregiver untuk berkumpul dengan keluarganya sendiri, berdampak pula terhadap kondisi emosional dan psikologis dari para caregiver. Hal ini lah yang kemudian dapat berkontribusi terhadap tingginya tingkat stres pada caregiver, (Ariesti, Ratnawati, \& Lestari, 2019). Seperti ditemukan oleh (Mubin, 2005) bahwa sebanyak 65 orang dari 67 perawat $(97 \%)$ mengalami stres dalam kategori rendah.

Stres merupakan ketidakmampuan mengatasi ancaman yang dihadapi oleh kondisi mental, fisik, emosional, dan spiritual yang berpengaruh terhadap kesehatan fisik individu. Stres merujuk pada hubungan tertentu antara individu dengan lingkungan yang nilai oleh individu tersebut sebagai situasi yang membebani, mengancam dan melebihi kemampuannya, (Barseli, Ifdil, \& Nikmarijal, 2017). Hal ini sesuai dengan yang dikemukakan oleh (Herbert \& Cohen, 1993) bahwa respon tak sehat terhadap stres terjadi ketika tuntutan dari sumber stres atau stressor melebihi kemampuan koping stres individu.

Secara alamiah, munculnya stres merupakan reaksi individu untuk menyesuaikan diri terhadap stressor atau sumber stres yang dihadapinya. Reaksi ini sangat mempengaruhi individu saat merespon stimulus dari lingkungannya. Stres yang dialami individu dapat berdampak positif ataupun negatif, tergantung pada bagaimana individu memberikan respon terhadap sumber stressor. Stres berdampak positif apabila individu dapat mengatasi stressor secara adaptif, dan akan berdampak negatif apabila individu tidak bisa mengatasi stressor secara adaptif, dan bahkan bisa menyebabkan munculnya berbagai gangguan perilaku pada individu, baik secara psikologis maupun fisik (psikosomatis).

Diperlukan upaya yang adaptif bagi individu dalam mengatasi stres yang dihadapinya, yang dikenal dengan istilah koping. Koping didefinisikan sebagai upaya yang dilakukan individu untuk mengatasi stressor baik dari dalam diri maupun dari lingkungan. Secara umum, individu akan menggunakan strategi koping yang sudah pernah digunakan dan berhasil, apabila koping tidak berhasil maka individu akan menyesuaikan dengan mengganti strategi koping lainnya,(Nursasi, 2002). Strategi koping adaptif bisa berupa relaksasi, olah raga, mengatur pekerjaan, dan dukungan eksternal, yang dapat menghasilkan kesehatan fisik dan mental, (Rosalina \& Nugroho, 2020).

Strategi koping sangat dibutuhkan oleh para caregiver, khususnya sangat 
menghadapi stressor dari tuntutan pekerjaan yang dilakukannya. Tuntutan kerja sebagai seorang caregiver yang harus profesional dalam menghadapi perubahan perilaku lansia yang cenderung tidak menentu, serta berbagai karakter dan permasalahan kesehatan lansia, dan hubungan sosial dengan sesame caregiver dapat mempengaruhi tekanan dalam bekerja dan menjadi sumber stres bagi caregiver. Setiap individu akan mengatasi stressornya secara berbeda-beda, penggunaan strategi koping stres yang baik diharapkan dapat mengatasi stres yang dihadapi para caregiver lansia. Dengan demikian, caregiver tetap dapat menjalankan pekerjaannya secara optimal dan profesional, dan terciptanya lingkungan kerja yang baik

\section{METODE PENELITIAN}

Penelitian ini bertujuan untuk mengetahui stres yang dialami caregiver lansia dan strategi koping yang digunakan oleh caregiver lansia di salah satu Panti Wreda yang berada di Kota Cirebon. Pendekatan penelitian yang digunakan adalah pendekatan kualitatif, (Sugiyono, 2008). Teknik Pengumpulan data dilakukan dengan melakukan wawancara dan observasi terhadap sumber data utama, yang mana dalam hal ini adalah para caregiver lansia. Caregiver yang dijadikan subjek/informan dalam penelitian ini berjumlah 3 orang.

\section{HASIL DAN PEMBAHASAN}

\section{Gambaran Stressor Caregiver Lansia}

Berdasarkan hasil penelitian, diperoleh gambaran mengenai sumber stres atau stressor pada caregiver lansia dalam beberapa kategori berikut.

1. Stressor yang Sering Muncul
Permasalahan yang seringkali muncul dan menjadi stressor bagi caregiver lansia diungkapkan oleh para informan menjadi beberapa kategori masalah, antara lain sebagai berikut.

a. Masalah Kebersihan

Kebersihan sangat penting dalam menjaga kesehatan individu maupun lingkungan. Hal yang dialami caregiver kebersihan menjadi permasalahan utama dalam merawat caregiver, karena kebersihan fisik dan lingkungan dari para lansia sepenuhnya ditangani oleh pada caregiver, meliputi urusan mandi, buang air kecil, buang air besar dan kebersihan kamar lansia.

b. Pola Makan yang Tidak Teratur

Pola makan lansia menjadi tidak teratur disebabkan oleh perbedaan selera makan dari para lansia, sehingga menyebabkan beberapa lansia lebih memilih jajan makanan dari luar.

c. Keluhan Lansia

Muncul perilaku kekanak-kanakan yang ditampilkan oleh para lansia, mulai dari mengeluh terkait makanan, bosan dengan keseharian di panti, dan perubahan kondisi emosional pada lansia yang mulai mengalami kepikunan.

2. Stressor yang Membuat Stres Caregiver

a. Kesejahteraan Finansial

Aspek kesejahteraan finansial menjadi hal yang memunculkan kekhawatiran dari para caregiver, kurang mencukupinya gaji yang diterima caregiver bisa mendorong tingkat stres apalagi ketika tuntutan pekerjaan yang tinggi tidak diimbangi dengan bayaran yang sesuai.

b. Waktu Bersama Keluarga Berkurang

Fokus dalam merawat lansia di panti otomatis menyebabkan berkurangnya waktu dari para caregiver dengan keluarganya di rumah, sehingga terkadang muncul perasaan 
rindu para caregiver untuk dapat berkumpul dengan keluarganya.

c. Respon Psikologis terhadap Stressor

Sedih; yaitu Perasaan sedih muncul ketika caregiver melihat kondisi dari para lansia, yang tidak terurus oleh keluarganya atau bahkan ditelantarkan oleh keluarganya.

Marah; yaitu Berbagai perilaku yang ditunjukkan oleh lansia terkadang menjadi stressor bagi para caregiver yang dapat memunculkan perasaan kesal dan marah. Perasaan ini, tidak hanya berkaitan dengan lansia yang dirawatnya, tetapi juga bisa datang dari pihak lain, baik menyangkut aspek materil maupun non materil. Cemas; yaitu Kecemasan juga dirasakan oleh caregiver, khususnya ketika melihat kondisi finansial dirinya sendiri yang dirasa kurang. Misalnya, tidak ada tunjangan pensiun untuk para caregiver, ataupun pesangon yang diterima caregiver memunculkan kecemasan akan masa depan dari para caregiver.

\section{Strategi Koping Stres pada Caregiver Lansia}

Stressor yang muncul dalam merawat lansia memicu penggunaan berbagai strategi koping yang biasa dilakukan oleh para caregiver. Strategi koping digunakan untuk melindungi diri dari tekanan-tekanan yang ditimbulkan oleh permasalahan dalam pekerjaan caregiver. Berikut adalah strategi koping yang digunakan oleh caregiver dalam mereduksi stres yang dialaminya.

1. Koping Berfokus pada Masalah (Problem Focused Coping)

a. Membentuk perencanaan (planful problem solving)

Tida ditemukan penggunaan strategi koping ini oleh para caregiver. b. Melakukan upaya agresif untuk mengubah keadaan yang menekan (confrontative coping)

Upaya yang dilakukan oleh caregiver dalam mereduksi stresnya adalah dengan mengungkapkan kemarahan atau rasa kesalnya kepada lansia secara langsung dan terbuka. Hal ini memunculkan sikap tegas dari para caregiver agar para lansia bisa mentaati peraturan yang ada di panti sehingga tidak bertindak seenaknya.

c. Mencari dukungan sosial atau orang lain (seeking social support)

Dukungan dari berbagai pihak sangat penting untuk para caregiver, baik dalam memberikan dukungan materil maupun nonmateril. Banyak pihak yang datang ke panti untuk mendukung dan peduli terhadap para lansia. Dukungan tersebut datang dari kalangan akademisi, dinas sosial, dinas kesehatan, perusahaan, maupun dermawan serta donatur bagi keberlangsungan panti dan kesejahteraan para lansia sekaligus caregiver. Selain itu, yang tidak kalah penting adalah dukungan dari sesama rekan caregiver dalam bertukar pengalaman dan juga cara mengatasi ketika dihadapkan pada situasi yang membuat stres.

2) Koping Berfokus pada Emosi (Emotion focused coping)

a. Mencari makna positif dari permasalahan dengan sikap religius (positive reappraisal)

Ketika permasalahan muncul dan dialami oleh caregiver, terkadang cara terbaik dalam mempersepsikan masalah tersebut secara positif. Mengambil hikmah dan pelajaran dari setiap masalah menjadikan karakter caregiver semakin kuat, selain itu pula akan lebih dapat memahami setiap individu (lansia) yang berada di panti. Kemudian, mendekatkan 
diri kepada Allah SWT. juga menjadi jalan bagi caregiver dalam memperoleh ketenangan dan mereduksi stres yan dialaminya. Tertanam pula dalam benak para caregiver bahwa pelayanan yang diberikannya yakni dengan cara merawat lansia diibaratkan sedang mengurus orang tua sendiri, sehingga dapat memunculkan perasaan ikhlas dalam menjalaninya.

b. Menerima tanggung jawab dengan penerimaan diri (accepting responsibility)

Tanggung jawab yang disertai penerimaan diri dapat menciptakan perubahan positif dalam diri caregiver. Setiap pengalaman dan permasalahan dalam pekerjaan caregiver bisa menjadi sarana instrospeksi diri dan juga rasa syukur. Selain itu, tanggung jawab dan penerimaan caregiver ditunjukkan dengan menghargai lansia, merawat dengan baik dan menerima keadaan dari para lansia.

c. Menahan diri dan mengatur perasaan (self-controlling)

Pengendalian diri juga dilakukan oleh caregiver dalam mengarahkan tingkah lakunya, guna mengendalikan emosi, tekanan ataupun hambatan. Keterbatasan fisik yang ditandai dengan penurunan kemampuan lansia memunculkan sikap kasih sayang dan afeksi caregiver.

d. Menghindar dari permasalahan (distancing)

Ketika stressor sudah sangat kuat, caregiver merasa perlu menunjukkan sikap bodo amat, yang dilakukan dengan cara pergi keluar dari lingkungan panti untuk menyegarkan kembali kondisi psikologis dan fisik dari para caregiver.

e. Melarikan diri dari masalah (escape avoidance)
Hal ini tidak dilakukan oleh para caregiver, dengan berbagai kondisi yang dialami caregiver tetap menjalankan tugasnya secara profesional.

Secara lebih jelas, berikut disajikan data intensitas penggunaan strategi koping oleh para caregiver di salah satu panti wreda yang berada di Kota Cirebon.

\section{Tabel 1.2}

Intensitas Kemunculan Strategi Koping

\begin{tabular}{|c|c|c|c|}
\hline \multirow{2}{*}{$\begin{array}{l}\text { Problem Focused } \\
\text { Coping }\end{array}$} & \multicolumn{3}{|c|}{ Intensitas } \\
\hline & $\begin{array}{c}\text { Inf. } \\
1\end{array}$ & $\begin{array}{c}\text { Inf. } \\
2\end{array}$ & $\underset{3}{\text { Inf. }}$ \\
\hline $\begin{array}{l}\text { Planful problem } \\
\text { solving }\end{array}$ & - & - & - \\
\hline Confrontative coping & + & + & + \\
\hline Seeking social support & ++ & ++ & - \\
\hline \multirow{2}{*}{$\begin{array}{l}\text { Emotion focused } \\
\text { coping }\end{array}$} & \multicolumn{3}{|c|}{ Intensitas } \\
\hline & $\begin{array}{c}\text { Inf. } \\
1\end{array}$ & $\begin{array}{c}\text { Inf. } \\
2\end{array}$ & $\underset{3}{\text { Inf. }}$ \\
\hline Positive reappraisal & +++ & ++ & ++ \\
\hline $\begin{array}{l}\text { Accepting } \\
\text { responsibility }\end{array}$ & ++ & ++ & ++ \\
\hline Self-controlling & +++ & ++ & ++ \\
\hline Distancing & + & + & + \\
\hline Escape avoidance & - & - & - \\
\hline
\end{tabular}

$\begin{array}{lll}\text { Keterangan } & : & \\ + & : & \text { Intensitas Rendah } \\ ++ & : & \text { Intensitas Sedang } \\ +++ & : & \text { Intensitas Tinggi } \\ - & : & \text { Tidak Dilakukan }\end{array}$

\section{PEMBAHASAN}

Berdasarkan hasil penelitian yang diperoleh dalam penelitian ini menunjukkan 
bahwa caregiver merasa sedih, kesal, cemas dan marah. Respon psikologis yang teridentifikasi dari caregiver dipicu oleh perubahan kepribadian maupun tingkah laku lansia. (C. A. Miller, 2015)) mengemukakan bahwa pengalaman merawat lansia dengan kepikunan dapat menimbulkan perasaan marah, ambivalen dan emosi yang tidak stabil, karena perubahan yang terjadi pada lansia. Selain itu, beban psikologis yang muncul pada caregiver lansia dengan kepikunan yaitu rasa marah, perasaan ini muncul karena perubahan tingkah laku lansia menjadi susah diatur dan rewel. (Spielberger, 2013) menyatakan bahwa marah merupakan emosi negatif yang dialami oleh individu, yang dapat menimbulkan suatu perasaan terganggu dan tidak nyaman. Kemarahan dapat disertai oleh tanda-tanda fisiologis berupa menegangnya otot-otot dan terjadinya percepatan peredaran darah.

Stres caregiver merupakan serangkaian proses yang membawa pada kondisi psikologis yang tidak disukai, dan reaksi psikologis yang muncul dalam rangka adaptasi dengan tuntutan peran sebagai pengasuh, (Larasati, 2013). Dari ketiga caregiver yang menjadi partisipan dalam penelitian ini, terindikasi dua orang yakni Inf. 2 dan Inf. 3 mengalami stres kategori ringan, kemudian Inf. 1 mengalami stres kategori sedang. Dua orang caregiver dengan kategori ringan yakni Inf. 2 dan Inf. 3 berjenis kelamin perempuan, sementara Inf. 1 berjenis kelamin laki-laki. Kategori stres yang berbeda bisa disebabkan oleh jam kerja yang berbeda pada setiap caregiver, Inf. 2 dan Inf. 3 hanya bekerja 8 jam sehari, sedangkan Inf. 1 bekerja selama 24 jam.

Faktor lainnya adalah mayoritas caregiver yang merawat lansia biasanya didominasi oleh perempuan, yang mana perempuan erat kaitannya dengan mengasuh atau merawat, termasuk ke dalam tatanan sosial dengan kepedulian tinggi apabila dibandingkan dengan laki-laki, (Widiastuti, 2019). Hal ini didukung pula oleh penelitian Miller dkk. (1995) bahwa terdapat perbedaan peran dalam pengasuhan yang disebabkan oleh perbedaan gender.

Faktor Pendidikan juga berperan penting dan merupakan faktor yang menentukan keefektifan strategi koping. Semakin tinggi jenjang Pendidikan seorang individu, maka akan semakin terlatih untuk dapat menyelesaikan masalah yang dihadapinya. Kemudian, faktor perbedaan suku dan budaya tidak mempengaruhi tekanan pada seorang caregiver, (B. Miller, Campbell, Farran, Kaufman, \& Davis, 1995).

Penelitian yang dilakukan oleh (Parks \& Novielli, 2000) tentang panduan praktis untuk merawat caregiver, mempelajari strategi untuk mengatasi kesulitan dapat membantu mengurangi beberapa stres yang dialami caregiver. Penelitian lainnya yang dilakukan oleh (Chen, Huang, Yeh, Huang, \& Chen, 2015) mengenai efektivitas intervensi strategi koping pada beban caregiver diantara caregiver pasien lanjut usia dengan kepikunan, menyebutkan intervensi psikososial dapat membantu caregiver untuk mengadopsi strategi koping yang lebih berfokus pada masalah dan dukungan sosial yang bermanfaat dalam hal mengurangi beban caregiver. Hal ini sejalan dengan penelitian dari De Weerdt yang mengatakan ada pengaruh yang kuat dari tingkat lamanya pengalaman dan tingkat pendidikan terhadap kemampuan untuk mengatur emosi. Pengaruh lamanya pengalaman dan tingkat pendidikan dapat 
bersifat langsung maupun tidak langsung terhadap pengaturan emosi, (Mubin, 2005).

(Lazarus \& Folkman, 1987) membagi strategi koping menjadi dua macam, yakni koping berfokus pada masalah dan koping berfokus pada emosi. (Octaviani, Herawati, \& Tyas, 2018) mengemukakan bahwa koping yang berfokus pada masalah biasanya dilakukan pada masalah yang masih dapat diperbaiki, sedangkan, koping yang berfokus pada emosi biasanya dilakukan pada masalah yang tidak dapat diubah atau diperbaiki.

Hal ini sesuai dengan pendapat (Maryam, 2017) yang mengatakan bahwa strategi koping berpusat pada masalah cenderung dilakukan jika individu tersebut yakin bahwa sumberdaya yang dimilikinya dapat mengubah situasi. Adapun strategi koping berpusat pada emosi cenderung dilakukan bila individu merasa tidak mampu mengubah situasi yang menekan dan hanya dapat menerima situasi tersebut.

Perbedaan pemilihan strategi koping ini juga dapat diukur dari kesehatan psikologisnya. Individu yang memiliki kesehatan psikologis yang baik, maka strategi koping yang dipilih cenderung pada problem focused coping. Namun sebaliknya, ketika kondisi kesehatan psikologisnya kurang baik atau bahkan buruk, individu tersebut lebih memilih menggunakan strategi emotional focused coping.

Adanya hal tersebut dapat disimpulkan bahwa strategi koping merupakan suatu proses yang dapat dilihat dari konsistensi dan stressor yang sama, sehingga dapat dikatakan bahwa individu tersebut cenderung menggunakan strategi koping problem focused coping maupun emotion focused coping.

\section{KESIMPULAN}

Berdasarkan hasil penelitian ini, ketiga caregiver di salah satu panti wreda yang berada di Kota Cirebon mengalami kategori stres yang berbeda. Inf. 1 mengalami stres kategori sedang, sementara Inf. 2 dan Inf. 3 mengalami stres kategori ringan. Adapun strategi koping yang digunakan oleh para caregiver meliputi: a) koping berfokus pada masalah (problem focused coping), yang dilakukan dengan melakukan upaya agresif untuk mengubah keadaan yang menekan (confrontative coping), dan mencari dukungan sosial atau orang lain (seeking social support); serta b) koping berfokus pada emosi (emotion focused coping), yang dilakukan dengan mencari makna positif dari permasalahan dengan sikap religius (positive reappraisal), menerima tanggung jawab dengan penerimaan diri (accepting responsibility), menahan diri dan mengatur perasaan (self-controlling), dan menghindar dari permasalahan (distancing)

\section{REFERENSI}

Ariesti, E., Ratnawati, R., \& Lestari, R. (2019). Phenomenology Study: Caregiver Experience In Nursing Elderly With Self-Care Deficit At Panti Werdha Panti Pangesti Lawang. Jurnal Ilmu Keperawatan: Journal of Nursing Science, 6(1), 29-42.

Ariyani, A. M. (2013). Lansia Di Panti Werdha (Studi Deskriptif Mengenai Proses Adaptasi Lansia Di Panti Werdha Hargo Dedali Surabaya). Jurnal Ilmu Sosial Dan Ilmu Politik.[Serial Online]. Http://Journal. Unair. Ac.

Id/FilerPDF/Aun517da884a4full.

Pdf.(Diakses Pada 10 Desember 2015). Barseli, M., Ifdil, I., \& Nikmarijal, N. (2017). Konsep stres akademik siswa. Jurnal Konseling Dan Pendidikan, 
5(3), 143-148.

Chen, H., Huang, M., Yeh, Y., Huang, W., \& Chen, C. (2015). Effectiveness of coping strategies intervention on caregiver burden among caregivers of elderly patients with dementia. Psychogeriatrics, 15(1), 20-25.

Cristanty, M., \& Azeharie, S. (2016). Studi Komunikasi Interpersonal Antara Perawat Dengan Lansia Di Panti Lansia Santa Anna Teluk Gong Jakarta. Jurnal Komunikasi, 8(2), 170-178.

Herbert, T. B., \& Cohen, S. (1993). Stress and immunity in humans: a metaanalysis review. PSYCHOSOMATIC MEDICINE-WASHINGTON-, 55, 364.

Larasati, A. (2013). Kepuasan perkawinan pada istri ditinjau dari keterlibatan suami dalam menghadapi tuntutan ekonomi dan pembagian peran dalam rumah tangga. UNIVERSITAS AIRLANGGA.

Lazarus, R. S., \& Folkman, S. (1987). Transactional theory and research on emotions and coping. European Journal of Personality, 1(3), 141-169.

Maryam, S. (2017). Strategi coping: Teori dan sumberdayanya. Jurnal Konseling Andi Matappa, 1(2), 101-107.

Miller, B., Campbell, R. T., Farran, C. J., Kaufman, J. E., \& Davis, L. (1995). Race, control, mastery, and caregiver distress. The Journals of Gerontology Series B: Psychological Sciences and Social Sciences, 50(6), S374-S382.

Miller, C. A. (2015). Nursing for wellness in older adults . Philaddelphia. Lippincott, Williams \& Wilkins.

Mubin, M. F. (2005). Koping Perawat Terhadap Stress Kerja Di Ruang Rawat Inap Bougenvile Rumah Sakit Telogorejo Semarang Tahun 2004. JURNAL LITBANG, 2(3).

Nursasi, A. Y. (2002). Koping Lanjut Usia terhadap Penurunan Fungsi Gerak di Kelurahan Cipinang Muara
Kecamatan Jatinegara, Jakarta Timur. Octaviani, M., Herawati, T., \& Tyas, F. P. S. (2018). Stres, strategi koping dan kesejahteraan subjektif pada keluarga orang tua tunggal. Jurnal Ilmu Keluarga \& Konsumen, 11(3), 169180.

Parks, S. M., \& Novielli, K. D. (2000). A practical guide to caring for caregivers. American Family Physician, 62(12), 2613-2620.

Rosalina, M., \& Nugroho, W. A. (2020). Analisis Tingkat Percaya Diri dan Motivasi Pencak Silat Pada Popda Kota Cirebon Tahun 2018. Jendela Olahraga, 5(2), 141-149.

Spielberger, C. D. (2013). Anxiety: Current trends in theory and research. Elsevier.

Sugiyono. (2008). Metode penelitian pendidikan:(pendekatan kuantitatif, kualitatif dan $R \& D$ ). Alfabeta.

Triwanti, S. P., Ishartono, I., \& Gutama, A. S. (2015). Peran Panti Sosial Tresna Werdha dalam Upaya Meningkatkan Kesejahteraan Lansia. Prosiding Penelitian Dan Pengabdian Kepada Masyarakat, 2(3).

Widiastuti, R. H. (2019). Beban Dan Koping Caregiver Lansia Demensia Di Panti Wredha. Jurnal Ilmu Keperawatan Komunitas, 2(1), 8-18. 